\title{
Asap Cair Kayu Sengon sebagai Chelating Agents Logam Timbal (Pb) pada Model Menggunakan Biji Kedelai (Glycine max)
}

\author{
DOI: $10.18196 / p t .2017 .070 .42-51$
}

\author{
Nur Rohmah Lufti A'yuni ${ }^{* *}$, Purnama Darmadji², Yudi Pranoto ${ }^{2}$ \\ ${ }^{1}$ STPP Magelang Jurluhtan di Yogyakarta, \\ Jl. Kusumanegara No.2 Yogyakarta, 55167, Telp. 0274-373479, Fax. 0274-375528 \\ ${ }^{2} J u r u s a n$ Teknologi Pangan dan Hasil Pertanian, Fakultas Teknologi Pertanian, Universitas Gadjah Mada, \\ Jl. Flora No. 1 Bulaksumur, Yogyakarta 55281, Telp/Fax: +62 274589797 \\ *Corresponding author, email:nurayuni.ais@gmail.com
}

\begin{abstract}
ABSTRAK
Kedelai (Glycine max) merupakan salah satu tanaman yang mempunyai kemampuan untuk mengakumulasi logam berat cukup tinggi. Oleh karena itu, biji kedelai perlu diberikan suatu pre-treatment supaya tidak terjadi akumulasi logam berat dalam tubuh manusia. Penelitian bertujuan untuk mengetahui pengaruh konsentrasi asap cair kayu sengon terhadap penurunan kadar logam timbal (Pb) biji kedelai dan mengetahui pengaruh senyawa penyusun asap cair kayu sengon terhadap penurunan kadar logam Pb biji kedelai. Penelitian menggunakan rancangan acak lengkap dengan tiga kali ulangan. Faktor yang diteliti adalah pengaruh konsentrasi asap cair kayu sengon terhadap penurunan kadar logam Pb biji kedelai dengan variasi 0; 12,5; 25; 50 dan 100 \% sebanyak 25 ml. Parameter yang diamati adalah penurunan kadar logam Pb biii kedelai, perubahan kadar asam, fenol, karbonil dan pH asap cair kayu sengon setelah khelasi serta penurunan kadar logam Pb karena pengaruh senyawa penyusun asap cair kayu sengon. Model cemaran logam Pb dibuat dengan mencemari biji kedelai menggunakan larutan Pb(NO3)2 sebesar 2 ppm. Hasil penelitian menunjukkan bahwa semakin besar konsentrasi asap cair kayu sengon maka penurunan kadar logam Pb biji kedelai semakin besar. Asap cair kayu sengon dengan konsentrasi 100 \% dapat menurunkan kadar logam Pb biji kedelai sebesar 59,12 \%. Senyawa karbonil asap cair kayu sengon mampu menurunkan kadar logam Pb biji kedelai tertinggi sebesar 46,42 \%, diikuti asam asetat sebesar 43,97 \% dan fenol sebesar 41,55\%.

Kata kunci: Asap cair kayu sengon, Logam Pb, Biji kedelai, Gugus fungsional
\end{abstract}

\begin{abstract}
Soybean (Glycine max) is one of the plants that strongly accumulate heavy metals. Therefore, soybeans need to be given a pre-treatment so that no accumulation of heavy metals in the human body. The aim of this study was to determine the influence of Paraserianthes falcataria (L.) Nielsen wood liquid smoke concentration to the reduction of Pb metal in soybean seeds and determine the influence of liquid smoke compounds to the reduction of Pb metal in soybean seeds. The study used a completely randomized design with three replications. Factor to be examined was the effect of liquid smoke concentration to the reduction of Pb metal in soybean seeds with variations 0; 12.5; 25; 50 and $100 \%$ by $25 \mathrm{ml}$. Parameters measured were Pb metal reduction, the changes of acid, phenol, carbonyl and pH liquid smoke after chelation and Pb metal reduction because of liquid smoke compounds. Model of Pb metal was made from soybean seeds that have been contaminated by Pb (NO3) 2 with the 2 ppm concentration. The results showed that the greater the concentration of liquid smoke, the greater the reduction of Pb metal. The liquid smoke with the 100\% concentration gives the highest reduction of Pb metal in soybean seeds 59.12\%. Carbonyl compounds of liquid smoke give the highest reduction of Pb metal in soybeans seeds $46.42 \%$, followed by acetic acid $43.97 \%$ and phenol $41.55 \%$.

Keywords: Paraserianthes falcataria (L.) Nielsen wood liquid smoke, Lead (Pb), Soybean seeds, Functional group
\end{abstract}

\section{PENDAHULUAN}

Penyerapan logam berat dari tanah yang telah terkontaminasi logam berat melalui akar tanaman dan deposisi langsung logam berat dari atmosfer ke permukaan tanaman merupakan dua penyebab utama akumulasi logam berat pada edible part tanaman pangan (Pruvot dkk., 2006 dalam Ping dkk., 2013). Kemampuan

akumulasi logam oleh tanaman ditentukan oleh kemampuan penyerapan dan transportasi intraseluler tanaman. Pada sel tanaman, logam berat tersimpan dalam vakuola membentuk senyawa kompleks antara logam dengan asam organik atau peptida pengikat logam (Yang dkk., 2005). Proses akumulasi logam berat pada tanaman 
meliputi a). pengangkutan logam melewati membran plasma sel akar, b). pengangkutan logam lewat xylem dan c). translokasi, detoksifikasi dan penyerapan logam oleh seluruh bagian tanaman dan tingkat selular (Lombi dkk., 2002). Salah satu logam berat yang dapat menimbulkan efek racun terhadap manusia adalah logam timbal $(\mathrm{Pb})$. Logam timbal $(\mathrm{Pb})$ dapat memberikan efek racun terhadap sistem syaraf, sistem urinaria, sistem reproduksi, sistem endokrin dan jantung (Palar,2008).

Tanaman kedelai (Glycine max) merupakan salah satu tanaman yang mempunyai kemampuan cukup tinggi untuk mengakumulasi logam berat (Bojinova dkk., 1994 dalam Ping dkk., 2013) padahal kedelai merupakan salah satu bahan pangan yang sering dikonsumsi masyarakat. Beberapa peneliti telah melaporkan adanya cemaran logam timbal $(\mathrm{Pb})$ pada biji kedelai. Kadar logam timbal $(\mathrm{Pb})$ biji kedelai di Fandong Cina Selatan sebesar 0,34 ppm (Ping dkk., 2013), Argentina sebesar 0,85 ppm(Lavado dkk., 2001) sedangkan Salazar dkk. (2012) melaporkan kadar logam $\mathrm{Pb}$ biji kedelai di Kordoba, Argentina Tengah berkisar 1,52-2,55 ppm. Andriyanto (2012) melaporkan bahwa kadar logam timbal (Pb) biji kedelai yang ditanam di lahan intensifikasi sebesar 0,63 ppm padahal menurut SNI 7387-2009, batas maksimal cemaran logam timbal $(\mathrm{Pb})$ biji kedelai sebesar 0,5 ppm (Anonim, 2009). Oleh karena itu, biji kedelai perlu diberikan suatu pretreatment untuk menurunkan kadar logam timbal $(\mathrm{Pb})$ sehingga mencegah terjadinya akumulasi logam timbal $(\mathrm{Pb})$ dalam tubuh.

Salah satu metode untuk menurunkan kadar logam berat adalah dengan menambahkan senyawa pengkhelat (chelating agents) untuk mengikat logam berat sehingga terbentuk senyawa kompleks antara logam berat dengan senyawa pengkhelat. Salah satu faktor yang mempenga- ruhi penurunan logam berat adalah konsentrasi chelating agents karena konsentrasi chelating agents akan mempengaruhi aktifitas gugus fungsionalnya. Mifbakhuddin dkk. (2010) melaporkan bahwa semakin tinggi konsentrasi larutan asam cuka maka penurunan kadar logam kadmium pada kerang hijau semakin besar.

Hartati (2015) melaporkan bahwa asap cair tempurung kelapa dapat digunakan sebagai chelating agents untuk menurunkan kadar logam timbal $(\mathrm{Pb})$ biji kedelai sebesar 63,41 \%. Senyawa penyusun asap cair tempurung kelapa, termasuk fenol memberikan efek penurunan terhadap kadar logam Pb biji kedelai. Tempurung kelapa merupakan kayu keras yang mempunyai kadar lignin lebih tinggi daripada kadar selulosa (Tilman, 1981). Novianty (2013) melaporkan bahwa tempurung kelapa mempunyai kadar lignin 46,29 \%. Hasil dekomposisi termal lignin menghasilkan fenol sehingga pirolisis bahan dengan kadar lignin tinggi akan menghasilkan asap cair dengan kadar fenol tinggi (Girard, 1992).

Kayu sengon merupakan salah satu kayu lunak (Siregar dkk., 2011). Kadar lignin kayu sengon sebesar 26,8 \% (Martawijaya dkk., 2005 dalam Ngadianto, 2012) sehingga pirolisis kayu sengon akan menghasilkan asap cair dengan kadar fenol lebih rendah daripada asap cair tempurung kelapa. Penggunaan kayu sengon untuk industri mebel yang semakin meningkat menyebabkan peningkatan limbah kayu sengon, salah satunya dalam bentuk potongan kayu. Selama ini, limbah potongan kayu sengon belum banyak dimanfaatkan. Penggunaan asap cair dari kayu keras sebagai chelating agents telah diteliti tetapi penggunaan asap cair dari kayu lunak belum diteliti sehingga perlu dilakukan penelitian untuk mengetahui efektivitas asap cair kayu sengon yang merupakan kayu lunak terhadap penurunan kadar logam timbal $(\mathrm{Pb})$ biji kedelai. 
Tujuan penelitian adalah untuk mengetahui pengaruh konsentrasi asap cair kayu sengon terhadap penurunan kadar logam timbal $(\mathrm{Pb})$ biji kedelai dan mengetahui pengaruh senyawa penyusun asap cair kayu sengon terhadap penurunan kadar logam $\mathrm{Pb}$ biji kedelai.

\section{BAHAN DAN METODE}

Bahan yang digunakan dalam penelitian adalah limbah potongan kayu sengon berukuran sekitar $4 \times 1 \times 1 \mathrm{~cm}$ sampai dengan 4 x 3,5 $\mathrm{x} 1,5 \mathrm{~cm}$ yang diperoleh dari perusahaan mebel di Gamping. Berdasarkan hasil analisis, kayu sengon mempunyai kadar air 9,23\%, hemiselulosa 23,78 \%, selulosa 51,81 \% dan lignin 17,22 \%. Biji kedelai varietas Anjasmoro dengan kadar air 12,2\% diperoleh dari lahan intensifikasi di Prambanan, Sleman. Bahan kimia yang digunakan untuk analisis kimia antara lain: larutan standar $\mathrm{Pb}\left(\mathrm{NO}_{3}\right)_{2} 1000$ ppm, $\mathrm{HNO}_{3}, \mathrm{HCLO}_{4}$, folin ciocalteu, asam asetat, fenol, aseton (Merck, Germany).

Penelitian ini menggunakan rancangan acak lengkap dengan tiga kali ulangan. Faktor yang diteliti adalah pengaruh konsentrasi asap cair kayu sengon terhadap penurunan kadar logam $\mathrm{Pb}$ biji kedelai dengan variasi $0 ; 12,5 ; 25 ; 50$ dan $100 \%$ sebanyak 25 ml. Khelasi logam Pb biji kedelai menggunakan senyawa asam asetat, fenol dan aseton dilakukan untuk mengetahui pengaruh senyawa penyusun asap cair terhadap penurunan kadar logam Pb biji kedelai. Parameter yang diamati adalah penurunan kadar logam $\mathrm{Pb}$ biji kedelai, perubahan kadar asam, fenol, karbonil dan $\mathrm{pH}$ asap cair kayu sengon setelah khelasi serta penurunan kadar logam $\mathrm{Pb}$ karena pengaruh senyawa penyusun asap cair kayu sengon. Data yang diperoleh dianalisis menggunakan ANOVA dilanjutkan dengan uji Duncan Multiple Range Test (DMRT) pada taraf kepercayaan $5 \%$ jika terdapat beda nyata antar perlakuan (Gomez dan Gomez, 1995).

\section{Pembuatan asap cair kayu sengon}

Kayu sengon terlebih dahulu dianalisis kadar air, hemiselulosa, selulosa dan lignin sebelum kayu sengon dipirolisis. Kayu sengon dipirolisis pada suhu $400{ }^{\circ} \mathrm{C}$ kemudian diendapkan selama 24 jam dilanjutkan dengan distilasi 2 kali pada suhu $98 \pm 2{ }^{\circ} \mathrm{C}$ (Kuntjahjawati dan Darmadji, 2004). Redestilat asap cair kayu sengon kemudian dianalisis kadar asam, fenol, karbonil dan $\mathrm{pH}$.

Pembuatan model cemaran logam timbal (Pb) pada biji kedelai

Larutan $\mathrm{Pb}\left(\mathrm{NO}_{3}\right)_{2}$ standar 1000 ppm diencerkan dengan aquademineral sehingga diperoleh larutan $\mathrm{Pb}$ dengan konsentrasi 2 ppm. Biji kedelai utuh dan kering sebanyak $100 \mathrm{~g}$ direndam dalam 500 ml larutan $\mathrm{Pb} 2$ ppm kemudian diaduk menggunakan magnetic stirrer selama 2 jam pada putaran $600 \mathrm{rpm}$. Biji kedelai utuh selanjutnya ditiriskan dan dikeringkan dengan cabinet dryer selama 24 jam pada suhu $50^{\circ} \mathrm{C}$. Kadar logam timbal $(\mathrm{Pb})$ biji kedelai dianalisis menggunakan AAS (Atomic Absorption Spectroscopy) pada panjang gelombang 283,3 $\mathrm{nm}$.

Proses khelasi logam Pb biji kedelai menggunakan asap cair kayu sengon

Proses khelasi logam $\mathrm{Pb}$ biji kedelai dilakukan dengan perendaman $5 \mathrm{~g}$ biji kedelai yang telah tercemar logam $\mathrm{Pb}$ direndam dalam $25 \mathrm{ml}$ asap cair kayu sengon dengan berbagai variasi konsentrasi yaitu 0 \%, 12,5 \%, 25 \%, $50 \%$ dan $100 \%$ kemudian diaduk menggunakan magnetic stirrer selama 2 jam pada putaran 600 rpm. Biji kedelai ditiriskan dan dicuci menggunakan $15 \mathrm{~mL}$ aquademineral sebanyak 2 kali selanjutnya dikeringkan dengan cabinet dryer pada suhu $50{ }^{\circ} \mathrm{C}$ 
selama 24 jam (Li dkk., 2010 yang dimodifikasi Andriyanto, 2012). Kadar logam timbal (Pb) biji kedelai dianalisis menggunakan AAS pada panjang gelombang 283,3 nm. Untuk mengetahui pengaruh masing-masing senyawa penyusun asap cair kayu sengon (asam asetat, fenol dan aseton) terhadap penurunan kadar logam Pb biji kedelai, makadipersiapkan larutan perendam dari senyawa asam asetat, fenol dan aseton dengan kadar yang sama dengan kadar asam asetat, fenol dan karbonilasap cair kayu sengon.

\section{Analisis kadar asam}

Analisis kadar asam mengacu metode AOAC (Anonim, 2005). Asap cair sebanyak $1 \mathrm{~mL}$ ditambah aquades sampai volume tepat $100 \mathrm{~mL}$ lalu dicampur sampai homogen kemudian ditambah 3 tetes indikator PP. Sampel dititrasi menggunakan $\mathrm{NaOH}$ 0,1 $\mathrm{N}$ sampai warna merah muda terbentuk (BM asam asetat $=60)$.

$\%$ asam asetat $=\frac{V \times \mathrm{N} \times \mathrm{BM} \times f_{p}}{m g_{\text {sampel }}} \times 100 \%$

Keterangan:

$\mathrm{V}=$ Volume $\mathrm{NaOH}(\mathrm{mL}), \mathrm{N}=$ Normalitas

$\mathrm{NaOH}(\mathrm{N}), \mathrm{BM}=$ Berat molekul asam asetat, $\mathrm{fp}=$ Faktor pengenceran

\section{Analisis kadar fenol}

Analisis kadar fenol mengacu metode Senter dkk. (1989). Asap cair sebanyak $1 \mathrm{~mL}$ diencerkan sampai volume tepat $100 \mathrm{~mL}$. Diambil $1 \mathrm{~mL}$ kemudian diencerkan sampai volume tepat 10 $\mathrm{mL}(\mathrm{fp}=1000 \mathrm{x}$ ). Hasil pengenceran diambil $1 \mathrm{~mL}$ dan ditambah larutan $5 \mathrm{~mL} \mathrm{Na}_{2} \mathrm{CO}_{3}$ alkali $2 \%$ dan dibiarkan selama \pm 10 menit. Selanjutnya sampel diambah larutan folin ciocalteu sebanyak 0,5 mL, divortex dan dibiarkan selama 30 menit. Absorbansi larutan sampel ditera dengan spektrofotometer pada panjang gelombang 750 nm. Konsentrasi larutan fenol dihitung berdasar- kan kurva standar yang diperoleh dari larutan fenol murni. Kadar fenol dihitung menggunakan rumus:

$\%$ fenol $=\frac{\mathrm{x} \cdot f_{p}}{m g_{\text {sampel }}} \times 100 \%$

Keterangan:

Nilai $x$ diperoleh dari regresi hasil kurva standar $y=a x+b$, dengan nilai y adalah hasil absorbansi sampel, $\mathrm{fp}=$ Faktor pengenceran

\section{Analisis kadar karbonil}

Analisis kadar karbonil mengacu metode Lappin dan Clark (1951). Asap cair sebanyak $1 \mathrm{~mL}$ diencerkan sampai volumetepat $25 \mathrm{~mL}$. Diambil $1 \mathrm{~mL}$ larutan sampel dan diencerkan sampai volume tepat $100 \mathrm{~mL}(\mathrm{fp}=2500 \mathrm{x})$. Hasil pengenceran diambil $1 \mathrm{~mL}$ dan dicampur dengan 1 $\mathrm{mL}$ 2,4-dinitrophenyl hidrazine dan 1 tetes HCL pekat. Selanjutnya sampel dipanaskan selama 30 menit pada suhu $50^{\circ} \mathrm{C}$. Campuran sampel didinginkan dan ditambah $8 \mathrm{ml}$ larutan $\mathrm{KOH}$ $1 \mathrm{~N}$. Absorbansi larutan sampel ditera dengan spektrofotometer pada panjang gelombang 480 $\mathrm{nm}$ (kuning).

$\%$ karbonil $=\frac{\mathrm{x} \cdot f_{p}}{m g_{\text {sampel }}} \times 100 \%$

Keterangan:

Nilai $\mathrm{x}$ diperoleh dari regresi hasil kurva standar $y=a x+b$, dengan nilai $y$ adalah hasil absorbansi sampel, $\mathrm{fp}=$ Faktor pengenceran

\section{Analisis kadar $\mathrm{Pb}$}

Analisis kadar $\mathrm{Pb}$ mengacu AOAC (Anonim, 2005). Ditimbang $1 \mathrm{~g}$ sampel biji kedelai yang telah dihaluskan kemudian dimasukkan ke dalam erlenmeyer. Ditambah $8 \mathrm{~mL} \mathrm{HNO}_{3}$. $\mathrm{HClO}_{4}$ dengan perbandingan 2:1. Erlenmeyer dipanaskan di atas hotplate sampai larutan menjadi jernih dan timbul asap putih. Erlenmeyer diturunkan dari hotplate kemudian didinginkan. 
Sampel dipindah ke dalam labu takar $25 \mathrm{~mL}$ dan ditambah aquades sampai volume tepat $25 \mathrm{~mL}$. Larutan sampel ditera dengan AAS pada panjang gelombang 283,3 nm.

Perhitungan kadar logam timbal $(\mathrm{Pb})$ adalah sebagai berikut:

Kadar $\mathrm{Pb}=\frac{A}{B} \times 25 \mathrm{~mL}$

Keterangan:

$\mathrm{A}=$ Konsentrasi logam $\mathrm{Pb}$ hasil pengukuran,

$\mathrm{B}=$ Berat sampel dalam $\mathrm{g}$

\section{HASIL DAN PEMBAHASAN}

Komposisi Senyawa Penyusun dan pH Asap Cair Kayu Sengon

Hasil analisis kadar senyawa asam, fenol, karbonil dan $\mathrm{pH}$ asap cair kayu sengon dapat dilihat pada Tabel 1.

Tabel 1. Komposisi senyawa penyusun dan pH asap cair kayu sengon

\begin{tabular}{cccc}
\hline Asam (\%) & Fenol (\%) & Karbonil (\%) & pH \\
\hline $5,27 \pm 0,10$ & $0,50 \pm 0,01$ & $6,84 \pm 0,07$ & 2,42 \\
\hline
\end{tabular}

Kadar senyawa asam asap cair kayu sengon sebesar 5,27 \%. Hasil analisis ini berada pada kisaran kadar asam asap cair yang dilaporkan Maga (1988) sebesar 2,8 - 9,5 \% maupun Tranggono dkk. (1996) sebesar 4,27 - 11,39\%. Kayu sengon mempunyai kadar selulosa dan hemiselulosa relatif tinggi sehingga dapat menghasilkan kadar asam relatif tinggi. Menurut Girard (1992), senyawa asam asap cair dihasilkan dari pirolisis selulosa.

Kadar fenol asap cair kayu sengon sebesar 0,50 \%. Hasil analisis ini berada pada kisaran kadar fenol asap cair yang dilaporkan Maga (1988) sebesar 0,2 - 2,9\%. Kadar fenol asap cair kayu sengon relatif rendah karena kayu sengon mempunyai kadar lignin rendah. Menurut Draudt (1963), pirolisis lignin menghasilkan fenol.
Kadar karbonil asap cair kayu sengon sebesar $6,84 \%$. Kadar karbonil hasil penelitian ini lebih tinggi daripada kadar karbonil yang dilaporkan Maga (1988) sebesar 2,6 - 4,6 \% tetapi lebih rendah daripada hasil penelitian Tranggono dkk. (1996) sebesar 8,56 - 15,23 \%. Perbedaan tersebut dapat disebabkan oleh perbedaan jenis kayu, kadar air, lama pirolisis, suhu pirolisis dan ukuran kayu (Darmadji dkk., 2000).

Nilai pH asap cair kayu sengon sebesar 2,42. Hal ini menunjukkan bahwa asap cair kayu sengon bersifat asam. Menurut Pszczola (1995), dalam asap cair terdapat berbagai jenis asam sehingga mempengaruhi $\mathrm{pH}$. Selain itu, asap cair kayu sengon juga mengandung senyawa fenol dan karbonil yang dapat berkontribusi terhadap tingkat keasaman asap cair kayu sengon. Menurut Sugoro dkk. (2012), adanya senyawa fenol, aldehid dan keton dapat menyebabkan keasaman media.

Pengaruh Konsentrasi Asap Cair Kayu Sengon Terhadap Penurunan Kadar Logam Timbal (Pb) Biji Kedelai Hasil Perendaman

Berdasarkan Gambar 1, konsentrasi asap cair kayu sengon berpengaruh terhadap penurunan kadar logam Pb biji kedelai. Asap cair kayu sengon dengan konsentrasi $100 \%$ mampu menurunkan kadar logam Pb biji kedelai sebesar 59,12 \%. Hartati (2015) melaporkan bahwa asap cair tempurung kelapa mampu menurunkan kadar logam Pb biji kedelai sebesar 63,41 \%. Perbedaan kemampuan khelasi asap cair kayu sengon dengan asap cair tempurung kelapa disebabkan perbedaan konsentrasi asam, fenol, karbonil yang merupakan senyawa penyusun asap cair.

Semakin tinggi konsentrasi asap cair kayu sengon maka penurunan kadar logam $\mathrm{Pb}$ biji kedelai semakin besar. Hal ini disebabkan semakin besar konsentrasi asap cair kayu sengon 
maka semakin banyak gugus fungsional karboksil, hidroksil dan karbonil dalam asap cair kayu sengon yang dapat berikatan dengan logam $\mathrm{Pb}$. Hashem dkk. (2005) menyatakan bahwa gugus fungsional pada senyawa asam, fenol dan karbonil dapat membentuk senyawa kompleks dengan logam. Gugus karboksil pada asam akan terdeprotonisasi menghasilkan ion $\mathrm{COO}^{-}$yang dapat berikatan dengan logam $\mathrm{Pb}$. Pada senyawa fenol, gugus hidroksil yang terdeprotonasi akan membentuk ikatan dengan kation logam (WitekKrowiak dan Reddy, 2013).

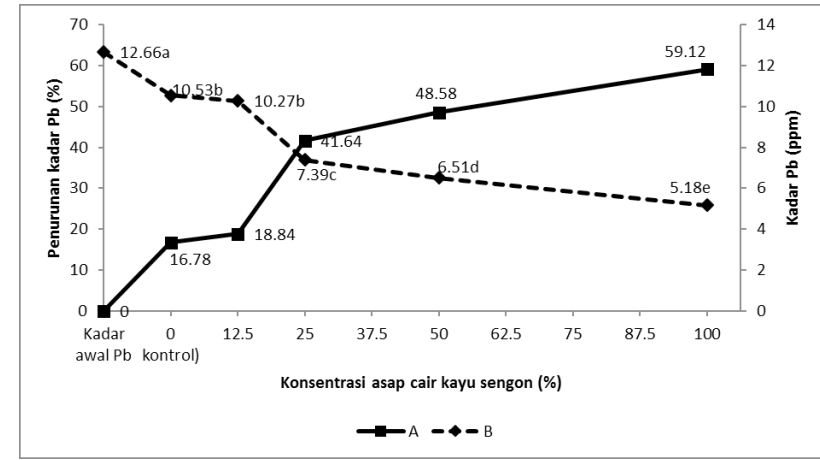

Gambar 1. Penurunan kadar logam Pb (\%) oleh asap cair kayu sengon

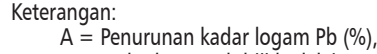

$B=$ Kadar logam Pb biji kedelai (ppm)

Tanda huruf yang berbeda menunjukkan hasil yang berbeda nyata pada alpha $5 \%$.

Penurunan logam $\mathrm{Pb}$ oleh asap cair kayu sengon kemungkinan juga disebabkan oleh $\mathrm{pH}$ asap cair kayu sengon yang rendah. $\mathrm{pH}$ asap cair kayu sengon yang relatif rendah (asam) diduga dapat mempengaruhi kekuatan ikatan antara logam $\mathrm{Pb}$ dengan protein kedelai sehingga ion $\mathrm{Pb}^{2+}$ dapat terlepas dari protein dan berikatan dengan gugus fungsional asap cair. Yuliasari dkk. (2011) menyatakan bahwa kekuatan ikatan antara logam dengan protein sangat berkurang dalam suasana asam. pH asap cair kayu sengon yang rendah juga mempengaruhi bentuk logam $\mathrm{Pb}$. Yoshida dkk. (2003) melaporkan bahwa spesies $\mathrm{Pb}$ (II) dapat ditemukan sebagai ion
$\mathrm{Pb}^{2+}$ secara dominan pada $\mathrm{pH}<6$. Ion $\mathrm{Pb}^{2+}$ yang bermuatan positif dapat berikatan dengan ion gugus fungsional asap cair kayu sengon yang bermuatan negatif. Hal ini sesuai dengan hasil penelitian Shofiyani dan Gusrizal (2006) yang melaporkan bahwa adsorpsi logam $\mathrm{Pb}^{2+}$ dalam jumlah tinggi terjadi pada kondisi asam atau $\mathrm{pH}$ 2-3. Tingginya adsorpsi logam $\mathrm{Pb}$ pada $\mathrm{pH}$ rendah menunjukkan bahwa mekanisme adsorpsi logam $\mathrm{Pb}$ didominasi oleh interaksi elektrostatik atau pertukaran ion logam $\mathrm{Pb}^{2+}$ dengan ion $\mathrm{H}^{+}$.

Perubahan kadar senyawa asam setelah digunakan untuk khelasi logam Pb

Asap cair kayu sengon setelah mengalami penurunan kadar asam setelah digunakan untuk khelasi logam Pb biji kedelai, seperti pada Gambar 2 .

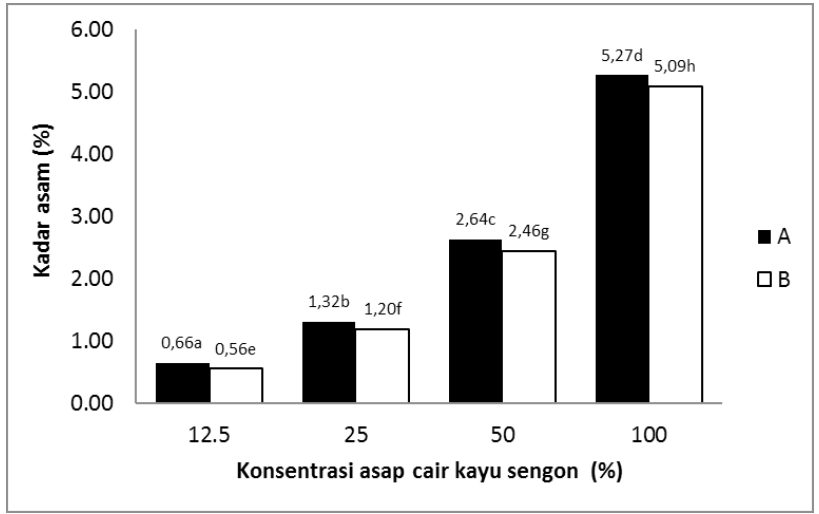

Gambar 2. Perubahan kadar asam asap cair kayu sengon (\%) sebelum dan setelah digunakan untuk khelasi logam Pb biji kedelai

Keterangan:

$A=$ Kadar asam awal $(\%)$,

$\mathrm{B}=$ Kadar asam akhir $(\%)$

Tanda huruf yang berbeda menunjukkan hasil yang berbeda nyata pada alpha $5 \%$.

Penurunan tertinggi kadar asam terjadi pada konsentrasi asap cair kayu sengon 12,5\% sebesar $15,15 \%$. Adanya penurunan kadar asam menunjukkan bahwa senyawa asam berperan terhadap penurunan kadar logam $\mathrm{Pb}$ biji kedelai. Hal ini disebabkan senyawa asam telah berikatan dengan logam $\mathrm{Pb}$ membentuk senyawa kompleks. Gu- 
gus karboksil $(\mathrm{COOH})$ pada asam yang terdeprotonisasi akan membentuk ion $\mathrm{COO}^{-}$yang dapat berikatan dengan muatan positif logam $\mathrm{Pb}$ membentuk senyawa kompleks antara $\mathrm{Pb}$ dengan asam. Hal ini sesuai dengan Sinaga dkk. (2013) yang melaporkan bahwa ion sitrat dapat mengikat logam sehingga dapat menurunkan ion logam yang terakumulasi pada kerang darah sebagai kompleks sitrat.

\section{Perubahan kadar senyawa fenol setelah digunakan} untuk khelasi logam Pb

Asap cair kayu sengon mengalami penurunan kadar fenol setelah digunakan untuk khelasi logam Pb biji kedelai, seperti pada Gambar 3.

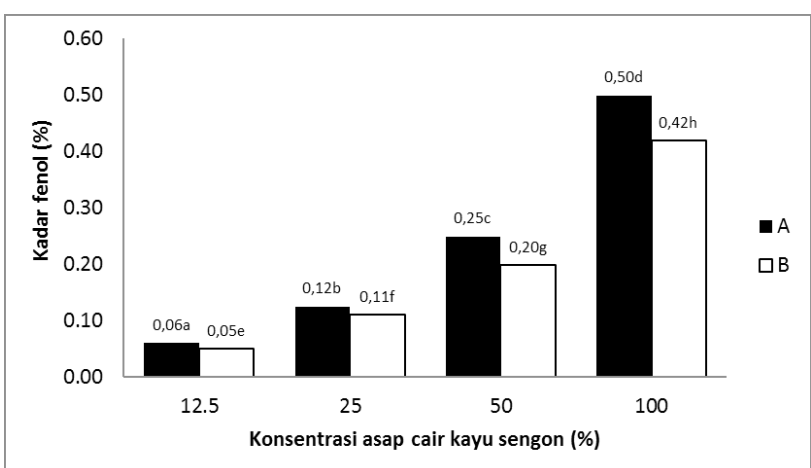

Gambar 3. Perubahan kadar fenol asap cair kayu sengon (\%) sebelum dan setelah digunakan untuk Keterangan: khelasi logam Pb biji kedelai

$A=$ Kadar fenol awal (\%),

$\mathrm{B}=$ Kadar feniol akhir (\%),

Tanda huruf yang berbeda menunjukkan hasil yang berbeda nyata pada alpha $5 \%$.

Penurunan tertinggi kadar fenol asap cair kayu sengon terjadi pada konsentrasi 50\% sebesar 20\%. Adanya penurunan kadar fenol menunjukkan bahwa senyawa fenol berperan terhadap penurunan kadar logam Pb biji kedelai. Penurunan kadar logam $\mathrm{Pb}$ oleh fenol disebabkan adanya ikatan antara ion logam $\mathrm{Pb}$ yang bermuatan positif dengan muatan negatif gugus fungsional hidroksil $(\mathrm{OH})$ fenol yang terdeprotonisasi. Hal ini sesuai dengan pernyataan Holde (1985) bahwa eugenol yang merupakan salah satu senyawa fenol dapat mengikat logam (L) menjadi eugenol logam dengan posisi logam terikat pada posisi gugus $\mathrm{OH}$ sehingga gugus $\mathrm{OH}$ dari eugenol berubah menjadi O-L.

\section{Perubahan kadar senyawa karbonil setelah digunakan} untuk khelasi logam Pb

Kadar senyawa karbonil asap cair kayu sengon juga mengalami penurunan setelah digunakan untuk khelasi logam $\mathrm{Pb}$ biji kedelai, seperti pada Gambar 4.

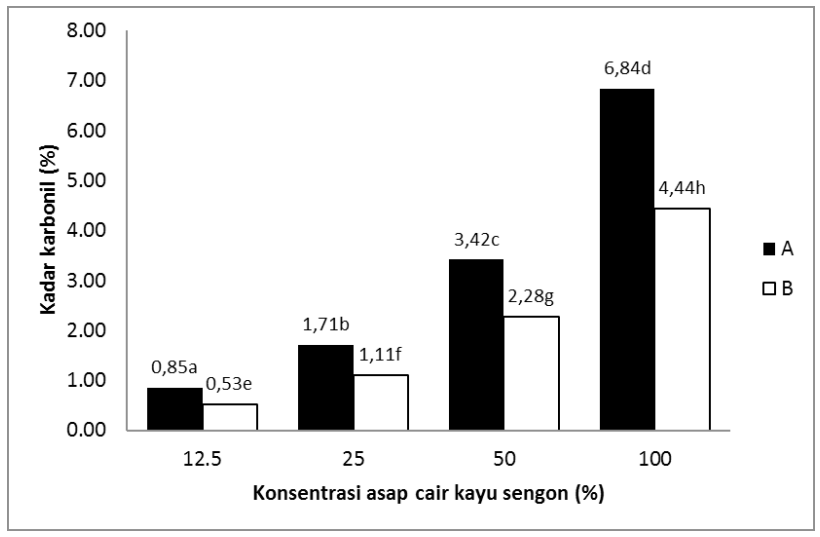

Gambar 4. Perubahan kadar karbonil asap cair kayu sengon (\%) sebelum dan setelah digunakan untuk khelasi logam Pb biji kedelai Keterangan:

$A=$ Kadar karbonil awal (\%),

$\mathrm{B}=$ Kadar karbonil akhir $(\%)$,

Tanda huruf yang berbeda menunjukkan hasil yang berbeda nyata pada alpha $5 \%$.

Penurunan tertinggi kadar karbonil terjadi pada konsentrasi asap cair kayu sengon $12,5 \%$ sebesar 37,65 \%. Hal ini menunjukkan bahwa senyawa karbonil berperan terhadap penurunan kadar logam Pb biji kedelai. Penurunan kadar logam $\mathrm{Pb}$ oleh senyawa karbonil diduga karena terbentuknya ikatan kovalen koordinat antara ion logam $\mathrm{Pb}^{2+}$ dengan atom oksigen dari senyawa karbonil sehingga kadar logam $\mathrm{Pb}$ biji kedelai mengalami penurunan. Ion logam $\mathrm{Pb}^{2+}$ merupakan elektrofil karena kekurangan elektron sehingga ion logam $\mathrm{Pb}^{2+}$ akan mendekati atom oksigen pada gugus karbonil yang bersifat 
nukleofil karena atom oksigen mempunyai dua pasang elektron bebas.

Hal ini sesuai dengan penelitian Harjanti (2008) yang melaporkan bahwa $\mathrm{Na}^{+}$akan mendekati posisi paling nukleofilik pada gugus karbonil sehingga $\mathrm{Na}^{+}$akan mendekati atom oksigen yang mempunyai dua pasang elektron bebas. Oksigen memberikan satu pasang elektronnya untuk dipakai bersama-sama dengan $\mathrm{Na}^{+}$ sehingga oksigen kekurangan elektron. Oksigen bersifat elektronegatif sehingga oksigen akan berusaha menarik pasangan elektron pada ikatan rangkap karbon. Oleh karena atom karbon (C) telah memberikan sebagian elektronnya untuk dipakai bersama oksigen, maka atom $\mathrm{C}$ pada ikatan rangkap menjadi bermuatan positif (carbocation atau $\left.\mathrm{C}^{+}\right)$.

\section{Perubahan kadar pH asap cair setelah digunakan untuk khelasi logam Pb}

Asap cair kayu sengon mengalami peningka$\tan \mathrm{pH}$ setelah digunakan untuk khelasi logam $\mathrm{Pb}$ biji kedelai, seperti terlihat pada Gambar 5.

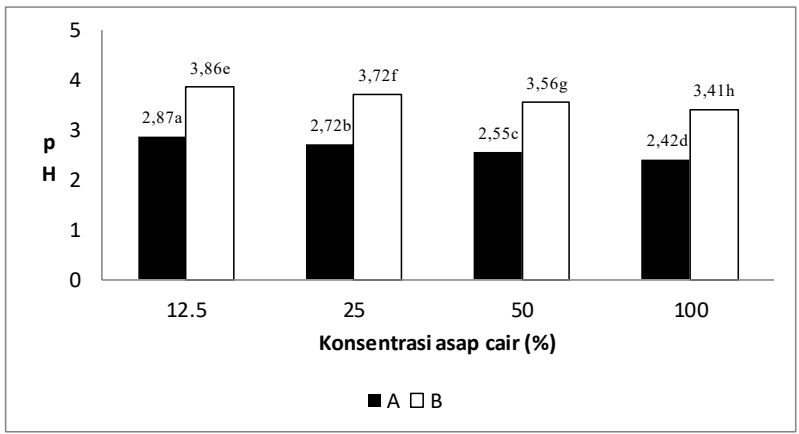

Gambar 5. Perubahan pH asap cair kayu sengon (\%) sebelum dan setelah digunakan untuk khelasi logam $\mathrm{Pb}$ Keterangan biji kedelai

$A=$ Kadar pH awal (\%),

$\mathrm{B}=$ Kadar pH akhir (\%),

Tanda huruf yang berbeda menunjukkan hasil yang berbeda nyata pada alpha $5 \%$

Peningkatan $\mathrm{pH}$ asap cair kayu sengon setelah digunakan untuk perendaman biji kedelai menunjukkan terjadinya penurunan tingkat keasaman pada asap cair kayu sengon. Hal ini disebabkan senyawa fungsional asap cair kayu sengon yang mempengaruhi keasaman asap cair telah berikatan dengan logam $\mathrm{Pb}$ membentuk senyawa kompleks. Terjadinya peningkatan $\mathrm{pH}$ asap cair kayu sengon setelah perendaman biji kedelai sesuai dengan hasil analisis kadar asam, fenol dan karbonil asap cair kayu sengon yang mengalami penurunan setelah perendaman biji kedelai sehingga menurunkan tingkat keasaman asap cair kayu sengon.

\section{Perubahan senyawa asap cair kayu sengon setelah digunakan untuk khelasi logam Pb}

Untuk mengetahui pengaruh masing-masing senyawa penyusun asap cair kayu sengon (asam asetat, fenol dan karbonil) terhadap penurunan kadar logam Pb biji kedelai, maka dilakukan khelasi logam $\mathrm{Pb}$ menggunakan senyawa asam asetat, fenol dan aseton. Konsentrasi senyawa asam asetat, fenol dan aseton yang digunakan untuk khelasi logam Pb biji kedelai berdasarkan kadar asam, fenol dan karbonil asap cair kayu sengon, masing-masing sebesar 5,27 \%; 0,5 \% dan $6,84 \%$.

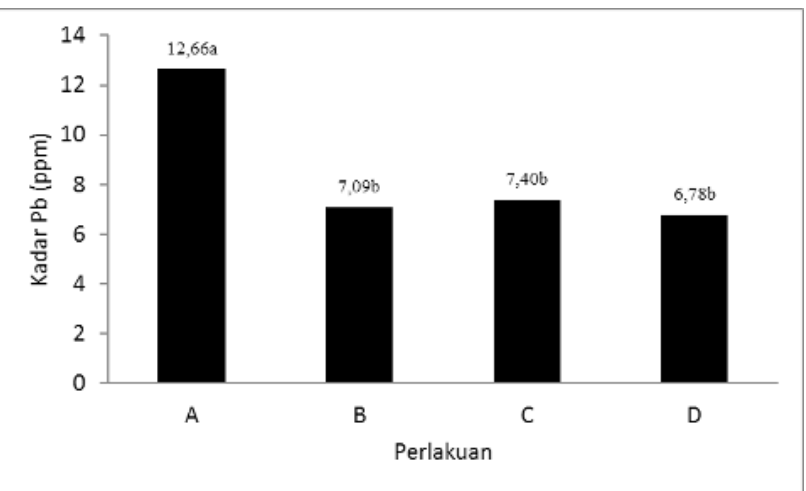

Gambar 5. Kadar logam Pb (ppm) biji kedelai setelah proses khelasi menggunakan asam asetat, fenol dan aseton

Keterangan:
$A=$ Tanpa perendaman

$\mathrm{B}=$ Perendaman asam asetat $5,27 \%$

$\mathrm{C}=$ Perendaman fenol $0,5 \%$

$\mathrm{D}=$ Perendaman aseton $6,84 \%$

Tanda huruf yang berbeda menunjukkan hasil yang berbeda nyata pada alpha $5 \%$ 
Berdasarkan Gambar 6, senyawa asam asetat, fenol dan aseton berperan terhadap penurunan kadar logam $\mathrm{Pb}$ biji kedelai. Asam asetat dengan konsentrasi 5,27 \% mampu menurunkan kadar logam $\mathrm{Pb}$ sebesar 43,97\%. Fenol dengan konsentrasi 0,5\% menurunkan kadar logam $\mathrm{Pb}$ sebesar $41,55 \%$ sedangkan aseton dengan konsentrasi 6,84 \% menurunkan kadar logam Pb sebesar 46,42\%. Penurunan kadar logam Pb biji kedelai oleh ketiga senyawa tersebut menunjukkan bahwa senyawa penyusun asap cair kayu sengon berpengaruh atau berperan terhadap penurunan kadar logam $\mathrm{Pb}$ biji kedelai.

\section{SIMPULAN}

1. Semakin besar konsentrasi asap cair kayu sengon maka penurunan kadar logam $\mathrm{Pb}$ biji kedelai semakin besar. Asap cair kayu sengon dengan konsentrasi $100 \%$ dapat menurunkan kadar logam $\mathrm{Pb}$ biji kedelai sebesar 59,12 $\%$.

2. Senyawa asam, fenol dan karbonil asap cair kayu sengon berperan terhadap penurunan kadar logam $\mathrm{Pb}$ biji kedelai. Senyawa karbonil dengan kadar 6,84 \% mampu menurunkan kadar logam $\mathrm{Pb}$ biji kedelai tertinggi sebesar $46,42 \%$, diikuti asam asetat dengan kadar $5,27 \%$ sebesar 43,97 \% dan fenol dengan kadar 0,50 \% sebesar 41,55\%.

\section{SARAN}

Perlu dilakukan penelitian tentang penggunaan asap cair kayu sengon sebagai chelating agents pada biji kedelai yang tercemar logam $\mathrm{Pb}$ secara alami. Dengan demikian, bisa diketahui kemampuan asap cair kayu sengon terhadap penurunan logam $\mathrm{Pb}$ yang terikat secara alami pada biji kedelai.

\section{DAFTAR PUSTAKA}

Andriyanto, 0. 2012. Pengikatan timbal (Pb) dan kadmium (Cd) pada biji kedelai (Glycine max) menggunakan asam asetat dan asap cair. Skripsi. Fakultas Teknologi Pertanian. Universitas Gadjah Mada. Yogyakarta.

Anonim. 2005.0fficial Methods of Analysis of Association of Official Analytical Chemist. $18^{\text {th }}$ ed. AOAC International. Gaithersburg. Maryland. USA.

Anonim. 2009. SNI7387:2009: Batas Maksimum Cemaran Logam Berat dalam Pangan. Badan Standardisasi Nasional. Jakarta.

Darmadji, P., H.A. Oramahi, Haryadi dan R. Armunanto. 2000. Optimasi produksi dan sifat fungsional asap cair kayu karet. Agritech 2(3):147 - 155.

Draudt, H.N. 1963. The meat smoking process:a review. Food Technology 17(12):85 - 90.

Girard, J.P. 1992. Technology of Meat and Meat Products. Ellis Horwood. New York.

Gomez, K.A. danA.A Gomez. 1995. Prosedur Statistik untuk Penelitian Pertanian (Terjemahan Endang Sjamsudin dan Justika S. Baharsjah). Universitas Indonesia Press. Jakarta.

Harjanti, R.S. 2008. Pemanfaatan zeolit alam klinoptilolite sebagai katalisator dalam alkoholis minyak jarak. Jurnal Rekayasa Proses 2(1):28 - 32.

Hartati, S., P. Darmadji, dan Y. Pranoto. 2015. Penggunaan asap cair tempurung kelapa untuk menurunkan kadar timbal $(\mathrm{Pb})$ pada biji kedelai (Glycine max). Agritech 35(3):331-339.

Hashem, A., E.S. Abdel-Halim, K.F. El-Tahlawy dan A. Hebeish. 2005. Enhancement of adsorption of Co (II) and Ni (II) ions onto peanut hulls though esterification using citric acid. Adsorption Science and Technology 23:367 - 380.

Holde, K.E.V. 1985. Physical Biochemistry. Prentice-Hall Inc. New York.

Kuntjahjawati dan P. Darmadji. 2004. Identifikasi komponen volatil asap cair daun tembakau (Nicotiana tabacum L.) rajangan. Agritech 24(1):17 -22.

Lappin, G.R. dan L.C. Clark. 1951. Calorimetric methods for determination of trace carbonyl compound. Analytical Chemistry 23:541 - 542.

Lavado, R.S., C.A. Porcelli, R.Alvarez, 2001. Nutrient and heavy metal concentration and distribution in corn, soybean and wheat as affected by different tillage systems in the Argentine Pampas. Soil and Tillage Research 62:55-60.

Li, Q., L. Chai, Q.Wang, Z.Yang, H.Yan dan Y.Wang. 2010. Fast esterification of spent grain for enhanced heavy metal ions adsorption. Bioresource Technology101: 3796-3799.

Lombi, E., K.L. Tearall, J.R. Howarth, F.J. Zhao, M.J. Hawkesford dan S.P. McGrath. 2002. Influence of iron status on calcium and zinc uptake by different ecotypes of the hyperaccumulator Thlaspi caerulescens. Plant Physiology 128:1359 - 1367.

Maga, J. 1988. Smoke and Food Processing. CRC Press Inc. Florida.

Mifbakhuddin, R. Astuti, A. Awaludin. 2010. Pengaruh perendaman larutan asam cuka terhadap kadar logam berat cadmium pada kerang hijau. Jurnal Kesehatan 3(1):14-20. 
Ngadianto, A. 2012. Karakteristik kayu mahoni dan kayu sengon dengan perlakuan pengawetan asap cair. Tesis. Fakultas Kehutanan. Universitas Gadjah Mada. Yogyakarta.

Novianty, H., 2013. Karakterisasi mikrokapsul asap cair tempurung kelapa menggunakan maltodekstrin, kitosan, alginat dengan spray dryer. Tesis. Fakultas Teknologi Pertanian. Universitas Gadjah Mada. Yogyakarta.

Palar, H. 2008. Pencemaran dan Toksikologi Logam Berat. Rineka Cipta. Jakarta.

Ping, Z., L. Zhi-An,Z. Bi,X. Han-Ping, W. Gang. 2013. Heavy metal contamination in soil and soybean near the Dabaoshan mine, South China. Pedosphere 23(3):298-304.

Pszczola, D.E. 1995. Tour highlight production and uses of smoke based flavors. Food Technology 49(1):70 - 74.

Salazar, M.J., J.H. Rodriguez, G.L Nieto, M.L. Pignata. 2012. Effects of heavy metal concentrations ( $C d, Z n$ and $\mathrm{Pb}$ ) in agricultural soils near different emission sources on quality, accumulation and food safety in soybean (Glycine max (L.) Merill). Journal of Hazardous Materials 233-234: 244-253.

Sinaga, D., Marsaulina, I. dan Ashar, T. 2013. Perbandingan penurunan kadar cadmium (Cd) pada kerang darah (Anadara granosa) dengan perendaman larutan jeruk nipis (Citrus aurantifolia) pada berbagai konsentrasi dan lama perendaman.http;//www. jurnal. usu. ac. id/ index. php/lkk/article/ download/3281/1607. Tanggal akses 1 April 2014.

Senter, S.D., J.A. Robertson danF.I. Meredith. 1989. Phenolic compound of the mesocarp of cresthauen peaches during storage and ripening. Journal of Food Science 54:1259 - 1268.

Shofiyani, A. dan Gusrizal. 2006. Pengaruh pH dan penentuan kapasitas adsorpsi logam berat pada biomassa eceng gondok (Eichhornia crassipes). Indonesian Journal of Chemistry 6(1):56 - 60.

Siregar, I.Z., Yunanto, T. dan Ratnasari, J. 2011. Prospek Bisnis, Budidaya, Panen dan Pascapanen Kayu Sengon. Penebar Swadaya. Jakarta.

Sugoro, I., Astuti, D.I., Sasongko, D. dan Aditiawati, P. 2012. Biosolubiliti lignit mentah hasil iradiasi gamma dan oleh Trichoderma asperellum. Jurnal Ilmiah Aplikasi Isotop dan Radiasi 8(1):21 - 30.

Tilman, D., 1981. Wood Combution: Principles, Process and Economics. Academics Press Inc. New York.

Tranggono, Suhardi, B. Setiadji, P. Darmadji, Supranto dan Sudarmanto. 1996. Identifikasi asap cair dari berbagai jenis kayu dan tempurung kelapa. Jurnal IImu dan Teknologi Pangan $1(2): 15$ - 24.

Witek-Krowiak, A. dan D.H.K. Reddy. 2013. Removal of microelemental $\mathrm{Cr}$ (III) and $\mathrm{Cu}$ (II) by using soybean meal wasteunusual isotherms and insights of binding mechanism. Bioresource Technology 127:350 - 357.

Yang, X., Y.Feng, Z. He, dan P.J. Stoffella. 2005. Molecular mechanism of heavy metal hyperaccumulation and phytoremedian. Journal of Trace Elements in Medicine and Biology 18:339353.

Yoshida, T, T. Yamaguchi, Y. lida and S. Nakayama. 2003. XPS study $\mathrm{Pb}$ (II) adsorption on $\mathrm{y}-\mathrm{Al}_{2} \mathrm{O}_{3}$ surface at high $\mathrm{pH}$ condition. Journal of Nuclear Science and Technology 40 (9): 672 - 678.
Yuliasari, N., Herlina dan W. Aprianto. 2011. Pengaruh asam asetat terhadap konsentrasi fe, cu dan protein daun eceng gondok(Eichornia crassipes). Jurnal Penelitian Sains $14(2 C): 28$ - 32. 